\title{
Entrepreneurial Networks Management in the Resource-Based Economic Sector on the Basis of Institutional Approach
}

\author{
Kalenskaya N.V. \\ Khusnutdinov R.N. \\ Grigoryeva L.L.
}

Kazan Federal University, Kazan, 420008, Russia

\section{Doi:10.5901/mjss.2014.v5n18p21}

\begin{abstract}
The article deals with the problem of forming business networks in the industrial sector of economy on the basis of institutional economics. Significant efficiency gains in the resource-based sectors as a whole can be achieved as a result of institutional design of enterprise networks based on the principles of cooperation and integrative solutions for the value chain. It is proved that the activities of industry sectors of small business can be significantly developed through the application of new institutional formats.
\end{abstract}

Keywords: business networks, petrochemical industry, entrepreneurship, institutional approach.

\section{Introduction}

During the years of its market transformation, Russian economy has significantly increased its orientation towards resources and this fact is supplemented by a remarkable number of negative phenomena and tendencies. In the presence of these resource-based economic conditions, suppression of entrepreneurial initiative is observed beyond this resource-based sector, as a result of this fact macro-economy is becoming less stable towards global risks and therefore the process of redistribution of the added value for the benefit of the extracting economic sectors and natural monopolies are fully displayed, the modernization processes of manufacturing and service economic sectors are de-stimulated.

At the same time the resource-based sector itself demonstrates dynamic development, large-scale investment programs and projects are formed in it, directed, e.g., to intensification of hydrocarbon materials processing, creation of infrastructure for transportation of resources abroad and others. Multiple positive effects of such projects are present. However, only technological solutions have limit of business effectiveness enhancement, moreover, the functioning of the big capital in a set of hydrocarbons extraction spheres is not rational. That is why for the given sector phenomenon of small oil companies is typical which function without the negative effects typical for vertically integrated structures. Industrial sector activities of small business could be significantly developed on the basis of new institutional formats and cooperative technologies use connected with application of cybernetic as well as synergetic approaches to management.

Preconditions for the institutional approach use in order to conduct research in this field are caused by the following reasons: countries supplied by resources frequently get into institutional traps, the classical examples being the so called «Dutch disease», «Venezuelan disease»; the network structures caused by localization of the economic agents relations are not also analyzed adequately on the basis of classical economic science; the economic modernization is possible in the format of the entrepreneurial network development which should consist of not only industrial sector but also complementary sector of economic knowledge, since the most important precondition for the formation and functioning of the innovative economy is cooperation between the participants of economic activity - universities, research institutes, laboratories, industrial enterprises, organizations of developers and small innovative enterprises, etc.

\section{Theory}

The entrepreneurial network by its definition possesses features of institutional entity since, compared with perfect competition, it is characterized by the common goal, clear structure, interdependency of the agents, relations with the external environment. This model has institutional background, since it decreases uncertainty in the external environment 
and transactional expenses of the market cooperation between the partners and, moreover, allows to provide flexibility of the network with the help of its elements structural configuration, to use achievements in the systematic approach in the form of integration between the industrial and territorial aspects, possibility of a broader use of infrastructural potential.

And the external efficiency of the entrepreneurial networks is influenced by the external environment which follows from the attribute of their openness and necessity to acquire production factors through the market mechanisms.

Taking into account the diversity of the relations and functional in the process of the added value creation, it is necessary to define the role of the entrepreneurial networks. We suppose that within the bounds of the above mentioned institutional approach the network type of the relations are in a large degree connected with the managing decisions and organizational innovations towards the reduction of transactional expenses. At the same time this approach is transformed in conditions of the resource-based economy where the small business share equals the functional as well as the service solutions, and entrepreneurial ability is aimed at profit extraction and creation of the value added in conditions of uneven distribution of resources. The entrepreneurial network relations in the given case stay not only in the sphere of «big business - small business» but also the sphere of «small business - small business», and also «small business - infrastructural networks».

The role of entrepreneurial networks in the resource-based economic sector is important, the entrepreneurial component being significant not only under conditions of Russian economy which is determined by universality of resources export model of economic development. At the same time for the resource-based sector itself two known in economic literature types of economic activity are urgent: the system of modules supposing the existence of large integrated and territorially isolated companies competing against each other in local markets, promoting horizontal integration and partly network type of entrepreneurial model for the branch with high fragmentarization of the values chain creation resulting in specialization of organizations and subsequent cooperative relations.

The resource-based sector in conditions of Russian economy can be developed within B2B sector (the network of extracting companies, service companies and suppliers). In a lower degree this concerns the network of consumers. The structure of oil and gas complex represents a set of vertically integrated structures of holding type, involving production and service enterprises and yet transformation of classical holdings into holding entrepreneurial structures which actively apply technological and managing entrepreneurial innovations.

Taking into account the existence of different countries participating in the processes of globalization, Russian specificity as an exporter of energy resources compared with the importers of resources is important. In the given sector low mobility and innovativeness of economy, underdeveloped service sector and low labor productivity are observed. Analyzed quantitative data indirectly prove the necessity of the competitive environment development for the basic natural resources (energetic) branches with the help of the entrepreneurial network, since Russian companies in regard to all natural resources branches are characterized by smaller net profits per each worker occupied in it. Restrictions of resources are the objective industrial preconditions for the development of entrepreneurial sector in oil industry: they are the exhaustion of unique and large fields, the increase of small fields share, the rise of remnant and hardly extractable reserves against a background of a sharp decrease in hydrocarbon reserves rise in the sub-soils of Russia. Therefore, a particular place in petroleum industry belongs to the phenomenon of small on the scale of economic activity type of enterprises. Their role is controversial and unequal for single regions of oil extraction.

\section{Results}

As a result of research on the entrepreneurial factors in conditions of Russian economy institutional problems are revealed: lack of the qualified personnel, unclearness of the economic situation, decrease in the use of information technologies, reduction of the medium-sized companies in their structure, consolidation of business as a whole in regard to larger enterprises, increase in cost of the entrepreneurial structures actives, though low technical equipment in manufacturing industries compared with the natural resources sector along with the fact of high stock market return. This and a number of other conditions prove the necessity of institutional solutions in the form of the entrepreneurial networks.

Activities by small petroleum companies require their perfection under conditions of the scale effect and small resources absence for realization of innovations. One way to solve this problem is to use organizational innovations and institutional approach directed to the provision of natural resources effect, specialization on services for big companies.

For the resource-based sector at the present time, the stimuli for introduction of innovative elaboration are being observed, and at the same time distribution of the stimuli in connection with the budget limitations are uneven. Big companies have notable resources but are not always interested in innovations because of the monopolistic position, small companies vise versa do not introduce high stimuli for innovations as a result of the lack of resources. This fact allows to speak about the existence of specialization in the innovative projects being brought into life. As a hypothesis, 
small business is oriented towards the process innovations, big companies - to technological and products innovations. Thus, the existing mechanisms stimulating innovations require institutionalization aimed at receiving additional effects connected with it.

Analysis of the small petroleum business sector realized for enterprises of oil consortium in the Republic of Tatarstan allowed to make the following important conclusions: a factor for business stability is its production powers, cost of which fluctuated insignificantly, low stability stock of companies' profits; a tendency for enlargement of small business enterprises was outlined; analysis of the small business readiness to solve innovative problems of the natural resources sector showed unevenness of the enterprises innovative activity, which requires the development of the centers of key competences.

From our point of view, as the initial moments of modeling should be considered the following: firstly, the basic controversy in logics of Russian economy development - dominance of the resource-based sector among branches by share of the created added value, secondly, modeling of the institutional environment to enhance effectiveness of the sector on the basis of the three-spiral model of innovations. It is important to take into account the first circumstance while choosing the criterion for global optimum, the second one is an instrument for its achievement by the appropriate managing innovations. Moreover, the network solution allows to overcome limits of the two-spiral relations in the given sector because of the phenomenon of final return increase. We shall construct modeling on the basis of the generalization of data on functioning of small oil companies as satisfying the model's conditions.

The initial moment for institutionalization of the entrepreneurial networks in the resource-based economic sector, as we suppose, is research of the general qualities of small oil companies on the basis of hierarchic cluster analysis. As a result all companies are generalized in groups similar in parameters of functioning (picture 1). Economic sizes of the enterprises became defining for the grouping.

At the same time hypothesis on the existence of the connection of clusterization with the indices of a single unit's functioning efficiency is interesting, and we checked it after application of another method of multi-measure statistical analysis - the method of the main components.

\section{Conclusions}

The conducted analysis allowed to reduce the matrix size of values up to the three components. Total contribution of these three components in dispersion of variables values equals $85 \%$ that corresponds to Pareto efficiency principle.
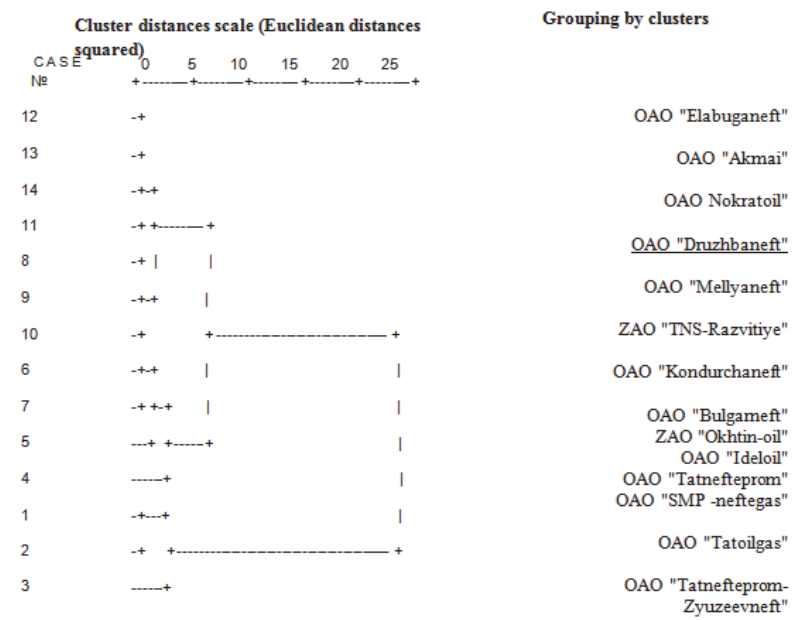

Fig. 1. Results of hierarchical cluster analysis (obtained by the author)

Interest from the point of definition of the resource proportions factors determining community of companies is the weight of each component in the dispersion in bold (table 1). The initial distribution of dispersion between the components was a sign of double exceeding of the first component over the second, and the second over the third. Resulted from rotation, the distributon of dispersion became more or less even: the first and the second components almost equaled contribution 
to the total dispersion, and the third slightly increased its contribution.

Table 1. Results of the main components method

\begin{tabular}{|c|c|c|c|c|c|c|c|}
\hline \multicolumn{4}{|c|}{ A) Matrix of the main components } & \multicolumn{4}{|c|}{ B) Component of the turned matrix } \\
\hline \multirow{2}{*}{ Initial index } & \multicolumn{3}{|c|}{ Component } & \multirow{2}{*}{ Initial index } & \multicolumn{3}{|c|}{ Component } \\
\hline & 1 & 2 & 3 & & 1 & 2 & 3 \\
\hline & 0,871 & & & Stock return & 0,953 & & \\
\hline \multirow[t]{2}{*}{ Stock return } & 0,844 & & & & 0,953 & & \\
\hline & 0,844 & & & & 0,924 & & \\
\hline \multirow{2}{*}{$\begin{array}{l}\text { Production capital funds } \\
\text { rentability }\end{array}$} & \multirow{2}{*}{0,786} & & & Technology & 0,817 & & 0,525 \\
\hline & & & & AV share & 0,734 & & \\
\hline Sales rentability & 0,775 & & & Earnings & & 0,944 & \\
\hline CFR & 0,743 & & & & & 0934 & \\
\hline Technology & 0,730 & $-0,543$ & & Profit & & 0,934 & \\
\hline Profit & 0,708 & 0,623 & & Production capital funds rentability & & 0,880 & \\
\hline AV share & 0,537 & & $-0,502$ & CFR & & 0,838 & \\
\hline Quantity & & 0,828 & & Sales rentability & & 0,643 & \\
\hline Earnings & 0,657 & 0,684 & & Quantity & $-0,524$ & 0,630 & \\
\hline Innovations & & & 0,917 & Innovations & & & 0,936 \\
\hline Dispersion & 47,6 & 25,6 & 12,0 & Dispersion & 37,2 & 35,1 & 13,0 \\
\hline
\end{tabular}

Newly obtained main components combine rather uniform initial indices. So, the first component integrated indices of the companies' functioning efficiency, among which are such important indices as the efficiency of the factors of production use (personnel, production funds, technologies, and precise indices of the formation of the value added per unit of personnel and the structure of earnings generally). Moreover, labor technologies enter the three components along with the innovation index that allows to aknowledge the thesis on the importance of integral service solutions in the given economic sector. That is why the first component could be named as «The efficiency of the entrepreneurial system» which is a part of the entrepreneurial network. The negative correlation between the quantity of the personnel and the first component is also interesting, and this fact indicates the importance of complex institutional solutions regarding companies' personnel within the entrepreneurial network.

The second component covers indices in a large degree caused by the scales of the entrepreneurial system functioning (earnings, profit, cost of noncurrent assets (assets outside of turnover), quantity of personnel) and indices of rentability of sales and funds derivative from them. That is why we shall name it «The provision of resources in the entrepreneurial system».

The third - the most important and not yet developed in conditions of Russian component - is «The innovative activity of the entrepreneurial system». We suppose that the problem of its development can not be solved by means of the separate entrepreneurial systems that is why the process of institutionalization and integration in light of this tendency of the development at the level of entrepreneurial networks is urgent.

As it was obtained from the conducted research the most important regulated parameter of the entrepreneurial network units functioning is the added value's share. Within the analysis of the choice of small oil companies, factors with extreme deviation were revealed which require special managing attention: quantity of the personnel and innovations. As a result of the correlation research it was exposed that resource factor does not have determining influence on the added value share, at the same time the efficiency of functioning is important for the provision of its high level. Since the efficiency of the resources extraction in the resource-based sector is closely connected with innovations, equation once again proves the importance of the entrepreneurial networks in the given economic sector. Moreover, on average the added value's share for small companies is higher than analogous index for large oil companies.

A set of preconditions revealed in the process of the conducted research was laid as a foundation for the anticipated environmental project stimulating the development of the competitive sector of the resource-based economy.

Fundamental preconditions for the institutional projecting are a set of theories which should be taken into account for the systematic approach to the problems being solved. Turning attention to the resource-based sector of economy and its development in the format of the entrepreneurial networks, it is necessary to considerate the achievements in Staple Theory, Sector Theory, Entrepreneurship Theories, Flexible Production Theory which are organically connected with the field of research being analyzed.

The purpose of the institutional projecting in the resource-based branch is stimulating positive - from the point of 
global optimum attributes of the resource-based sector - functioning and its separate parts. The entrepreneurial network was chosen as an object for projecting which, on the one hand, should be characterized by attributes of the developed competitive environment, on the other hand, more organized and inbuilt into mezzo-economic system of management being a variant of the cybernetic under-system unlike chaotically organized market relations.

In order to model the structure of the entrepreneurial network we shall use the equation of regression, prefacing which we shall analyze coefficients of variation aimed at the exposure of network activities indices requiring in the first place regulating and institutionalization of the approaches to management. Finally, we obtained the following economic mathematic model of the functioning efficiency of the entrepreneurial network agent in the resource-based economic sector (formula 1).

(1) AV share $=79,93+3,95 * E E S-1,95 * \mid A E S$

Where AV share - the added value's share in organization's earnings;

EES - integral index «Efficiency of the entrepreneurial system»;

IAES - integral index «Innovation activity of the entrepreneurial system».

The conducted activity modeling of the typical representative in the entrepreneurial network in the resource-based economic sector allows to bring into life the institutional projecting of infrastructural units stimulating their development. In the thesis characteristic features of the sphere being projected and managing technologies of the projecting provision were suggested.

\section{References}

Bagautdinova N.G., Gafurov I.R., Kalenskaya N.V., NovenkovaA.Z Territorial Marketing as Successful Strategy for Regional Development. $3^{\text {rd }}$ Annual International Conference Qualitative and Quantitative Economics Research (QQE 2013): 18-23, 2013.

Bagautdinova N.G., Gafurov I.R., Kalenskaya N.V., Novenkova A.Z. The Regional Development Strategy Based on Territorial Marketing (The Case of Russia). World Applied Sciences Journal 18 (Special Issue of Economics): 179-184, 2012;

Melnik A.N., Mustafina O.N. The Organization of Russian Power Market in Modern Conditions // Middle-East Journal of Scientific Research 13. - 2013. - P. 91-94.

Bagautdinova N.G, Sarkin A.V., Averyanov B.A., Arzhantseva N. The Consept of "New" Paternalism and Its Realisation within The State Regualtion of Econom// Mediterranean Journal of Social Sciences.- Vol.5, No12, (2014)-pp.27-32.

Hanssens, H., Derudder, B., Witlox, F. Are advanced producer services connectors for regional economies? An exploration of the geographies of advanced producer service procurement in Belgium // Geoforum, 2013. pp. 12-21.

Bagautdinova N.G, Sabitov N.H, Salakhov B.R.,. Shakhnina I.Z Regional Banks in the System of Government Regulation of Economy/l Mediterranean Journal of Social Sciences.- Vol.5, No12, (2014)-pp.39-42.

Huning, S., Naumann, M., Bens, O., Hüttl, R.F. Transformations of modern infrastructure planning in rural regions: The case of water infrastructures in Brandenburg, Germany // European Planning Studies19 (8) , 2011. pp. 1499-1516

Melnik A.N., Lukishina L.V., Khabibrakhmanov R.R. Methodological Foundations of the Formation of the Energy Strategy of an Enterprise // World Applied Sciences Journal. 2013. v. 23 (8). Pp. 1085-1089.

Bagautdinova N.G., Tsaregorodtsev E., Kulalayeva I., Arzhantseva N. Assessment of Mutual Probabilistic Influence of Volatility of Official Price for Precious Metals on the Market Value of the Bi-Currency Basket/l Mediterranean Journal of Social Sciences.Vol.5, No12, (2014)-pp.33-38.

Sadriev A.R. Problems and prospects of networking mechanism using in energy systems innovation development // Middle-East Journal of Scientific Research. - 2013. V. 17 (10). - pp. 1453-1456.

Panasyuk M.V., Pudovik E.M., Sabirova M.E.. 2013. Optimization of regional passenger bus traffic network // Procedia Economic and finance. Volume 5, pp. 589-596.

Huning, S., Naumann, M., Bens, O., Hüttl, R.F. Transformations of modern infrastructure planning in rural regions: The case of water infrastructures in Brandenburg, Germany // European Planning Studies19 (8) , 2011. pp. 1499-1516

Parr, J.B. The Regional Economy, Spatial Structure and Regional Urban Systems // Regional Studies. 2013. 
